\title{
UM SOFRER NECESSÁRIO: ESTUDO ETNOGRÁFICO SOBRE O SIGNIFICADO DA VACINAÇÃO DE CRIANÇAS NA ÓTICA DAS MÃES
}

\author{
A necessary suffer: An etnographic study about the meaning \\ of children's vaccination in mother's point of view \\ Un sufrir necesario: Estudio etnográfico sobre el significado de vacunación \\ de niños en la optica de las madres
}

Maria Lucia De Araújo Leopoldo

Marisa Antonini R.Bastos

0 objetivo deste trabalho foi compreender a experiência vivenciada pelas mães ao levarem seus filhos para serem vacinados. Ao considerá-las como um grupo cultural que compartilha dessa experiência, buscamos descrever seus conhecimentos e sentimentos, assim como valores, crenças e significados ${ }^{1}$ atribuídos por elas à vacinação de seus filhos. A fim de compreendermos esse universo de significados, utilizamos a estratégia teórico-metodológica da etnografia de Spradley e, como método de coleta de dados, a observação da participante, a análise documental e as entrevistas etnográficas com as informantes, mãe das crianças vacinadas no Instituto da Criança e do Adolescente em Juiz de Fora, Minas Gerais Brasil. A partir da análise dos dados obtidos, emergiu o tema "um sofrer necessário" como o mais significativo na ótica das mães, tornando-se o tema central do estudo. A melhor compreensão da experiência vivenciada pelas mães na vacinação dos filhos ${ }^{3}$ possibilitou-nos um cuidar mais holístico, oferecendo maior segurança às mães na tomada de decisão na vacinação dos filhos.

Palavras-chave: Vacinação. Etnografia. Saúde da Criança. Mães. Enfermagem.

This work was aimed at understanding the situation experienced by the mothers who take their children to be vaccinated. By regarding them as a cultural group which shares the same experience, we attempted to describe their knowledge and feelings as wellas their values, beliefs and the meaning ${ }^{1}$ they attribute to their children's vaccination. In order to better understand this whole networ of meanings, we used the theoretical methodological technique of ethnographyand, of Spradly ${ }^{2}$ as a data collecting method, the participant observation, the analysis of documents and the ethnographic interviews with the informants - the mothers of the children vaccinated at the Child and Youth Institute in Juiz de Fora, Minas Gerais - Brasil. Based on the data collected, a theme coined "necessary suffering" came up as being the most significant one in the mother's view, becoming the core of the study. A better understanding of the situation experienced by the mothers with regard to their children' $s^{3}$ vaccination allowed us a more holistic care, offering the mothers more safety in making up their minds on this issue.
El objetivo de este trabajo fué comprender la experiencia vivida por las madres al llevar sus hijos para que sean vacunados. Al considerarlas como un grupo cultural que comparte de esa experiencia, buscamos describir sus conocimientos y sentimentos, además de valores, creencias y signicados ${ }^{1}$ atribuidos por ellas a la vacunación de sus hijos. Con el fin de que pudiéramos comprender esse universo de significados, utilizamos la estrategia teórico metodológica de la etinografia y, en Spadly ${ }^{2}$ como método de colecta de datos, la observación participante, la análisis documental y las encuestas etnográficas con informantes, madres de los ninõs vacunados en Instituto da Criança e do Adolescente en Juiz de Fora - Minas Gerais - Brasil. Atráves del análisis de los datos obtenidos, emergió el tema un sufrir necesario como el más siginificativo en la optica de las madres, convertiéndose el tema central de la investigción. La mejor comprensión de la experiencia vivida por las madres en la vacunación de los hijos ${ }^{3}$ nos posibilitó un cuidar más holistico, ofereciendo mayor seguridad a las madres en la decision de vacunar sus hijos.
Keywords: Vaccination. Anthropology Cultural. Child Health. Mothers. Nursing.
Palabras clave: Vacunación. Antropología Cultural. Salud del Ninõ. Madres. Enfermería. 


\section{Referências}

1. Minayo MCM. 0 desafio do conhecimento: pesquisa qualitativa em saúde. Rio de Janeiro (RJ): ABRASCO; 1996.

2. Spradley J. The etnographic intervew. New York (USA): Rinehart \&Winston. 1989.

3. Almeida MM. Organização de serviços de imunização. In: Farhat CK et al. Imunizações: fundamentos e prática. São Paulo (SP): Atheneu, 2000.

\section{Nota}

aDissertação de Mestrado defendida em setembro de 2002 na Escola de Enfermagem da Universidade Federal de Minas Gerais -UFMG

Master's Degree Dissertation defended in september of 2002 in the School of Nursing/UFMG.

Dissertation del Master defendida en sptiembre de 2002 en Escuela de Enfermeria /UFMG.

\section{Sobre as Autoras}

Maria Lucia de Araújo Leopoldo

UFJF/ Juiz de Fora - MG. e-mail: Iuleo16@terra.com.br

\section{Marisa Antonini Bastos}

UFMG/ Belo Horizonte - MG. 